\title{
Translation as the mutual reflection of neighbouring nations (About the cultural activity of Kornél Szenteleky)
}

\author{
ZOLTÁN ViRÁG \\ Szegedi Tudományegyetem Bölcsészettudományi Kar, Egyetem utca 2-6, \\ HU-6722Szeged,viragz@hung.u-szeged.hu
}

\begin{abstract}
Razprava na podlagi konteksta pripovedk, romanov in esejev Kornéla Szentelekyja obravnava doživljajske tipe, življenjske izkušnje, značilno topografijo in zvrsti avtorjevega življenjskega dela. Avtor povezuje vloge, govore in izkušnje pomanjkanja, ki se odražajo v delih Szentelekyja, z markantnimi usmeritvami hrvaške, srbske in slovenske proze. Predstaviti skuša eksistencialna prizorišča ter okvire del Kornéla Szentelekyja, in sicer skozi multietničnost, manjšinske identitete, periferije, kulturne križpote in doživljanje travm.
\end{abstract}

In the context of Kornél Szenteleky's volumes of short stories, novels and essays, this essay examines the types of disposition, life experience, typical topographies and genres of the author's epic works. The roles, stock of phrases and experiences of deprivation present in the world of Szenteleky's short stories, novels and essays relate his prose to several authors of a significant trend in Croatian, Serbian and Slovenian literature. The essay observes the existential spaces and boundaries of Szenteleky's oeuvre, viewing it as going along the trails of existential experience of multiethnicity, minority identity, peripheral existence, cultural crossroads and traumas.

Ključne besede: Kornél Szenteleky, kulturni aktivizem, regionalna identiteta, multietničnost, izkušnja pomanjkanja, vzajemna refleksivnost

Key words: Kornél Szenteleky, cultural activism, regional identity, multiethnicity, experience of deprivation, mutual reflexivity

In March 1943, Zoltán Csuka, János Herceg, Károly Szirmai, Jenő Koltay-Kastner, Jenő Krammer and many more authors, literary critics and patrons of art gathered in Zombor (Sombor) to establish for the third time (after 1934 
and 1937) the Literary and Artistic Society named after Kornél Szenteleky. Luckily, the joint struggle of the 40 ordinary and the 18 honorary members, the maintenance of their own periodical called Kalangya, and the publication of a couple of important books proved to be a lasting project. However, in the mother country, very few people had heard of the namesake of the society, a conscientious doctor who healed the sick in Szivác and rode his bicycle tenaciously among the hills of Telecska (Telečka) in order to help Catholic Serbians, Croatians, Hungarians, Germans and Serbs in need. His pleasant-sounding name in front of the titles of his poems, short stories, novels, dramas, literary correspondence, travelogues, essays and articles was known only to a few.

As a doctor, he was persistently working on alleviating the pain of his patients; as an artist, on supporting and encouraging the authors of Bácska; and as an enthusiastic co-ordinator of cultural life, he considered the communication of cultures, the facilitation of dialogue between neighbouring nations, and the interpretation of origins (relieved from restrictive ideology) his duty. To prevent or moderate cultural lapses of memory, we should still evaluate him as an outstanding intellectual, a member of a group of authors with a western cultural heritage, writers dealing with peasants in their narratives, charismatic organizers, modernists breaking with old forms, ardent and pure poets, short story writers raising the problems of the lower middle class, vexed, tormented and suffering novelists struggling with ghosts and mists, militantly arguing turbulent spirits, rebels with social ills, and enthusiastic polemists of religion (see Draskóczy 1944: 250) all gathered together. A literary, artistic, social and economic weekly periodical called Híd, published only for a few volumes in Budapest and edited by Lajos Zilahy, the remarried widow of Kornél Szenteleky (Sztankovics), recalled the position and the contemporary evaluation of Szenteleky in the following way: "He mentioned one of his fellow writers who was considered to be less talented than he was many times. But his fellow remained in Budapest and became famous. He returned home to Bácska to become the supporter of minority writers/writers of minority literature" (Komáromi 1944: 250).

The provincial mentality, theoretical principles of local colour, mannerisms of narration, or the naked and spicy usage of peasants did not really allow Kornél Szenteleky to distance himself from the infinite quagmire of the country, the drab world of roads leading nowhere, houses yawning and standing empty all day long. On the other hand, his activity "could never be characterized by his leadership controlling others of opposing ideas, for which we can find so many examples from the history of culture, but (disregarding all his merit) by the consciousness of his own valid perspective" (Thomka 1992a: 90-91). His excellent knowledge of languages and the openness and the comprehensive nature of the artistic, musical, literary and philosophical directions of his interests enforced a definite approach and attitude, with the help of which he continuously reshaped and in his gradual reinterpretation fulfilled the tradition respecting, reconciled immersion in couleur locale, saveur locale, and esprit locale. At the 1933 Pen World Congress, his authoritative gesture as a writer, translator and 
editor manifested his faith, conscientiousness, and positive attitude toward intellectual life in Bácska in a special edition containing German, English, French, Italian, and Serb opening announcements. His intellectual quietism was of a pretty broad perspective because it included the neighbouring other as well as the distant other worlds, while he consistently tried to reveal the experiences imprinted in the national consciousness, the latent patterns of identification, and the problems of national identity.

The realization of the importance of local history, the obvious proofs of the dreariness of the country, the innumerable relics of chronicle-based narration, the versatility of figures used in the local dialects, and the autobiographical parade of authors all contributed to the spread of the plain style and to the universal dilettantism of the Hungarian literature of Voivodina. On the other hand, the mimicry of multiple bonds was brought into being by all these factors. Thus, an excellent opportunity was created for an extension of meaning and an interrelatedness of different artistic and literary cultures. In this atmosphere, the high standard needed for the depiction of the homeland and its regions could be appreciated. Folklore became important not only because of its own canons, but because it was considered to be a real and creative source of quality because of its undiscovered and still unpublished ideas. The comprehensive values and the increased and expanded proportions of poems, fiction, translations, letters, essays, critiques, travelogues written by Kornél Szenteleky were strong components of the decisive role of "culture, cultural tradition and the intellectual life of Europe" (Thomka 1992b: 95), and to the constant evaluation of origins and different forms which constitute real Europeanness in the cultural sense.

The prolific connections and fruitful interaction of interethnic dialogue can never be fulfilled in the mother tongue only, but with a balanced mixture of languages and cultures existing side by side, in a capacity for dialogue and the mutual recognition of otherness that can "accept the risk and the unforeseeable consequences of the communication of identities and can persevere in diversity" (Losoncz 2002: 276). It is not by chance that in Kornél Szenteleky's works, transforming universal culture into his own and the first-hand experience of mixed cultures culminates in thematic groups of stressed importance, such as foreignness, forlornness, homelessness, the national character, the love of culture, the difficulties of language, and the problems of belonging to a minority group. Thus, the works of Szenteleky, who considered himself a short story writer, are worth paying attention to despite their fundamental differences in quality and fluctuation of standards. They are not only evidence of a valuable life, they initiate substantial co-operation, surpassing superficial gestures of sympathy and empathy coming from the intersection of boundaries of language and cultures.

In the short stories "Viszontlátás" (1925, "The Meeting"), "Párizsi virág" (1925, "Flower of Paris"), "Üllöi úton" (1926, in Üllöi Road), "Suta este" (1927, "Lame Evening"), "Levél egy másik világba" (1927, "Letter to Another World"), "Gáláns kaland” (1928, "Gallant Adventure"), "Szindbád utolsó estéje” (1928, "The Last Evening of Sindbad"), "Tilike már tízéves múlott" (1929, "Tilike Is 
Already More Than Ten"), "Érvényesülni!" (1933, “To Succeed") and in the novels Kesergö szerelem (1914, Lamenting Love) and Isola Bella (1931), montages of time and place, methods for making the country seem improbable, spheres resisting memory of the essence cut out from the landscape and surroundings, scenery like artistic stylistic marks, and the recurrent metaphorical and metonymical devices make it obvious to what extent the spaciousness of the horizon cannot be regarded equal to the impression created by the eyes. The mingling of languages and cultures, transition, migration, and relocation are realized in the thrill of qualities worthy of constant renewal, so as to shed light on the gradually shrinking scope of the individual living in an ethnic minority.

The structure of the novel Isola Bella deconstructs the fable with a digressive technique of narration; the subjectivity of the protagonist appears as he positions himself as a point without co-ordinates in the different spheres outside language and the modes of existence. Immersed in cultural heterogeneity, Szabolcs Szabó retreats to fissures of momentary illusions, loses himself in tiny details of images, cosy moods, myriads of snatches of memory, and dissolves totally in the neutrality of time. The text touches upon the problems of the mother tongue, fate and origin, and can be compared to the thoughts of Miroslav Krleža in a number of his narrative works. However, the text does not naturally share Krleža's mercilessly offensive ideas regarding the whole Hungarian cultural sphere. In the world of the novel, which can be closely connected to short stories such as "Horvát rapszódia" ("Hrvatska rapsodija", 1917, "Croatian Rhapsody"), "Hodorlahomor, a Nagy" ("Hodorlahomor, Veliki", 1919, "Hodorlahomor, the Great"), "Magyar királyi honvéd novella" ("Kraljevska ugarska domobranska novela", 1921, "The Short Story of the Hungarian Royal Soldier"), "In extremis" ("In extremis", 1923, "In Extremis"), "Krizsovec Iván" ("Ivan Križovec", 1926, "Ivan Križovec"), "Marcel Faber-Fabriczy szerelme" ("Ljubav Marcela Faber-Fabriczyja za gospođicu Laura Warroniggovu", 1929, "The Love of Marcel Faber-Fabriczy"), "Temetés Terézvárott" ("Sprovod u Terezienburgu", 1929, "Burial in Terezienburg"), "Doktor Gregor első találkozása a Gonosszal" ("Kako je doctor Gregor prvi put u životu susreo Nečastivoga", 1929, "Doctor Gregor's First Encounter with the Devil"), and "Klanfár föispán első lakodalma" ("Svadba velikog župana Klanfara", 1929, "The First Wedding of Lord Lieutenant Klanfar"), the human and the national dimensions can be modified and supplemented. The essence of existence cannot necessarily be defined as the national state, the closed and pure ethnic group, or the ideal and the categories of racial and religious superiority: "The restriction of human beings is awfully rough, and the constant emphasis on the national character can be the reason why they cannot understand each other, why they protect the borders with bayonets and why they believe all sorts of unfounded incitement." In this work the question of national independence goes back to the tradition of folk music and songs in order to exemplify the difference in living connections between the majority and the minority, the mother country and the recipient country, the refugee and the immigrant, and the hybrid and the subordinate with the stylized anthropomorphism of Europeanness. 
Kornél Szenteleky was trying to create an emblematic tableau vivant of cultural and regional identity to promote his cultural and scholarly mission, and to raise awareness of the importance of language in his essays and critical writings, such as "Nyelvi problémák" (1931, "Problems of Language"), “Népiességünk” (1931, “Our Popular Character”), “A mi irodalmunk” (1932, “Our Literature”), "Irodalmi önképzés" (1932, "Literary Self-Education”), “A helyes kritika" (1932, “The Proper Criticism”), "Egy dunai kultúrterv” (1932, “A Danubian Cultural Plan”), “Szétforgácsolódás felé?” (1932, “Towards Dissipation?") and "Az új kritikus feladata" (1932, “The Duty of the New Critic"). He evaluated the territorial relations of Eastern Central Europe and compared the fundamental differences of views with a perfect respect for autonomy and sovereignty so as to find possibilities to lessen the distances, and moderate the tensions between old and fixed habits of behaviour, like me and the Other, us and them, the wish and the fear, forbearance and confrontation. In the tolerant intellectual foundations of "Egy dunai kultúrterv" ("A Danubian Cultural Plan") he expressed the goals and the necessary conditions of a possible selfdefinition brave enough to get rid of national spasms and obsessions: 'We do not know each other. At the moment five nations coexist by the Danube, in one geographical area, but they are foreign to each other in their languages and cultures. All Danubian states except for Austria embody national unity. This can be the explanation of strict cultural uncommunicativeness and the economical chauvinism. This is why we cannot know each other. Moreover, a person with a strong wish to know the other has to overcome a number of obstacles, the accusation of treason, and the difficulties of untrodden paths to reach his goal.

The nations of Danube basin are similar to each other in relation to culture; there are no significant differences considering the minds of the people, as the culture, psyche, temperament, and character development of a nation are much more influenced by geographic, climatic and economic factors than by race relations. The best example of this is the United States of America, which unites many different races with different cultures and views of life. Exaggerating the differences and emphasizing racism are weapons of the impatient, provoking type of politics, but real culture can never be intolerant; it considers every culture its kin, primarily those of neighbouring and therefore similar nations. We have to go back to the root of the problem, says Le Bon. We have to know each other, says the timely commandment adapted to our situation.

Kornél Szenteleky was not philosophising about the dominance of a selfaggrandizing idiom or the forced establishment of some temporary ethnic identity, but he envisioned an ethno-cultural and ethnographic diorama in which "ethnic self-recognition is being built in the intersection of cultures with the recognition of differences and similarities, the promotion and protection of intellectual and critical autonomies" (Bányai 1996: 48). At that time, for lack of unified collaboration Szenteleky's well-founded positivist plan, revealing the influence of a series of articles entitled Dunavska konfederacija written by Veljko Petrović and published from August 1930 in Belgrade in a newspaper called Politika, and vividly evoking the mentality of Endre Ady, might have 
seemed utopian (see Bori 1994: 78). Nevertheless, in his observations, Kornél Szenteleky, surpassing Endre Ady and Veljko Petrović, who was well-known for his enthusiasm for the national and cultural emancipation of his country, threw a new and special light on the mental map of moving frontiers and on the easing of interethnic differences by highlighting and differentiating the connections and factors of racism and history from the relations of the mutual recognition of each other.

With his sophisticated originality, the European from Szivác could point out the basic differences between atav(ist)ic and composite cultures, the former going back to remote ancestors and obscure privileges, the latter gaining benefit from diversity and a mixture of values. In general, atav(ist)ic culture deduces its right to legitimize its supremacy over a territory, treating it as its own thereafter from some myth of origin and the connected genealogy. The founding myth, no matter how dubious and obscure it is, from the very beginning authorizes the given community to understand their existence as the absolute continuity of genealogy and to consider the given piece of land their own national territory. The possibility of the expansion of legitimacy preserved in the consciousness of the community is judged as a lawful heritage on the basis of which the borders of this territory can be modified and expanded anytime, to any direction. ${ }^{1}$ Szenteleky was in favour of a complex, versatile type of culture which facilitates having more roots, making it possible to live out one's composite identity; what's more, it regards the homeland as more precious than a place of practising favouritism and of maintaining privileges. His attempts to liberate the individual and his observations in connection with making the borders unnoticeable were summed up in the memorable criteria of Népiességünk (Our Popular Character), based on the starting point of Nyelvi problémák (Problems of Language) including enduring intellectual preparation and the mastery of languages: "Not a single one of us wants to live a primitive amoebic life, to be enclosed in a narrow-minded world and to be unable to see further than the ocean of the human soul and culture. We can only be the cells of a huge organism, the universal human culture, in which these cells can have specific roles in the whole organism, but they cannot exist independently. Our popular character cannot be understood as negation, but as a force of development in the eternal construction of human culture. We are far from imprisoning ourselves in the otherwise open spiritual world of our community and forgetting about Europe and the perennial Catholicon: the great human universality."

His principles, built on an awareness of the transience of frontiers, his personal and professional contacts with excellent Croatian, Serbian and Slovenian poets, novelists and translators, the basic need for a mutual shaping of attitudes, the broadening of perspectives and the simultaneous, comprehensive apprehension of spaces in-between, decisively influenced the fundamental experience

\footnotetext{
${ }^{1}$ About the detailed description and characterization of atavic and composite cultures see Glissant (1996: 59-62).
} 
of (minority) existence in the kaleidoscope of different cultures and languages in his writings. It cannot be simple coincidence that in this well-grounded intellectual field and cultural environment we can find graduates from famous universities of Western Europe, travellers of the world, diplomats, leaders of artistic groups, and committed supporters of establishing contact with and mediating between translators of English, German, French, Italian, Croatian, Serbian, Slovenian and Hungarian literatures. One of these, Jovan Dučić, was a philosophy and sociology major student at the University of Geneva, knew Paris perfectly well, worked as a diplomat in Istanbul, Sofia, Athens, Cairo, Rome, Bucharest, Lisbon and whose whole intellectual orientation was aiming for the interpretation of authenticity and Europeanness; another, Veljko Petrović, who was a lawyer in Budapest, edited magazines in Zagreb and Sarajevo, was an active propagator of newspapers in Geneva, and in whose writings the atmosphere of Zombor, the mentality and local history of Ravangrad, have an outstanding role; Svetislav Stefanović was a doctor of medicine, too, but studied literature and was interested in the Anglo-Saxon mentality; Oton Župančič studied philosophy, history and geography in Vienna, and was employed by noble families as a private tutor while he travelled all around Europe; finally, Todor Manojlović studied law in Budapest, but adored Florence and other centres of art; moreover, at the university of Basel he studied art history, then edited newspapers in French and Italian, later organized artistic groups from the fans of modern trends, knew and translated the works of Gyula Juhász, Lajos Kassák, Endre Ady, about whom he also wrote essays, just like about Apollinaire, and in his memoirs he recorded his memorable meetings with prominent European artists. This list could be significantly widened to include Ivo Andrić, Miloš Crnjanski and Mladen Leskovac, with whom Crnjanski corresponded regularly.

Constant growth and enrichment were the keynotes of Szenteleky's unluckily short but versatile and meritorious career as a doctor, writer, translator, editor, cultural organizer, cyclist and drummer. Szenteleky was always trying to assess and compare the contrast of the centre and the periphery, the time factors of multi-directional memory, the historical situations, the periodization, social practice, institutional circumstances, artistic and literary arrangement of the difficulties of the free choice and use of languages, of the formation national self-recognition, of the possibility of independence, and of the revelation of denomination in such a way as to recognize their differences as the components of their inner identity (see Biti 2000: 91-92).

Szenteleky's intellectual world, which necessitated co-operation with the Other, and urged a change of tone of trustworthy authors, has not lost any of its validity and novelty through the decades. The main reason for this was that because he wanted to moderate the unavoidable colonizing tendencies, he was fundamentally aware of the common fate of co-existing nations. If the national consciousness of a nation can be successfully deduced from its respect for the intellectual and material values of other nations, in the spirit of Kornél Szenteleky we should be fully aware of the mutual reflection of nations in order to 
avoid the minority region's imprisonment in its myths and prejudices, resulting in a literary, artistic and political (hyper-)culture.

\section{BIBLIOGRAPHY}

János BÁNYAI, 1996: Kisebbségi magyaróra. Újvidék: Forum.

Vladimir BITI, 2000: Strano tijelo pri/povijesti (Etičko-politička granica identiteta). Zagreb: Hrvatska sveučilišna naklada.

Imre BORI, 1994: Szenteleky Kornél. Újvidék: Forum.

Ede DRASKÓCZY, 1944: Magyar kisebbségi irodalom a Délvidéken. Délvidéki Szemle 6.

Edouard GLISSANT, 1996: Introduction à une poétique du Divers. Paris: Gallimard. József Sándor KOMÁROMI, 1942: A költő képe a kedves szívében. Hid, 1942/ január 20.

Alpár LOSONCZ, 2002: Európa-dimenziók. Újvidék: Forum.

Beáta THOMKA, 1992: Prózatörténeti vázlatok. Újvidék: JMMT.

\section{PREVOD KOT VZAJEMNA REFLEKSIJA SOSEDNJIH NARODOV (KULTURNA DEJAVNOST KORNÉLA SZENTELEKYJA)}

Razprava želi s pomočjo analize delovanja Kornéla Szentelekyja dokazati, da avtorjevo prisvajanje univerzalne kulture in njegova neposredna izkušnja medkulturnih prepletanj ne vodita zgolj naključno k posebno pomembnim temam o tujstvu, sirotstvu, brezdomstvu, narodnem značaju, ljubezni do kulture, o jezikovnih in manjšinskih težavah. Dela avtorja, ki sebe prišteva med noveliste, kljub različni in nihajoči kakovosti, niso le dokumenti spoštljive življenjske poti, ki jo je potrebno ohraniti, temveč jih je potrebno še naprej graditi, in sicer v upanju odpiranja vsebinskega sodelovanja, ki presega navidezne geste simpatij in empatij do sečišča jezikovnih in kulturnih meja.

Prispevek predstavlja odločilen vpliv sistema pogledov (ki je bil izdelan v zavesti minljivosti meja in s pomočjo poznanstva $\mathrm{z}$ odličnimi hrvaškimi, srbskimi ter slovenskimi pesniki, pisatelji in prevajalci), širitve obzorij, vsestranskega istočasnega občutenja vmesnih prostorov na temeljno doživetje (manjšinske) biti v kaleidoskopu različnih kultur in jezikov v delih Kornéla Szentelekyja. 